\title{
The Great Gulf of Aqaba 1995 Earthquake Design Response Spectra over Sinai Peninsula and Some Jordanian Soils
}

\author{
Mohamed A. Gamal, Ahmed Abdelwahed \\ Geophysics Department, Faculty of Science, Cairo University, Giza, Egypt \\ Email:magamal@sci.cu.edu.eg,wahmed@sci.cu.edu.eg
}

How to cite this paper: Gamal, M.A. and Abdelwahed, A. (2019) The Great Gulf of Aqaba 1995 Earthquake Design Response Spectra over Sinai Peninsula and Some Jordanian Soils. International Journal of Geosciences, 10, 463-480.

https://doi.org/10.4236/ijg.2019.104027

Received: February 19, 2019

Accepted: April 27, 2019

Published: April 30, 2019

Copyright () 2019 by author(s) and Scientific Research Publishing Inc. This work is licensed under the Creative Commons Attribution International License (CC BY 4.0).

http://creativecommons.org/licenses/by/4.0/

(c) () Open Access

\begin{abstract}
The Gulf of Aqaba area is considered one of the most terrific touristic areas in the Middle East. The aim of the present work is to determine the amount of seismic hazards that the constructions may suffer due to seismic activities. This is done by determining the design response spectrum for this area from available earthquake response spectra, then taking into consideration the soil response for some Egyptian and Jordanian soils. The main shock of the November 22, 1995, the Gulf of Aqaba and its aftershocks were mainly used in producing the design response spectrum. This earthquake was considered as the biggest earthquake that hit this area since 160 years. Its magnitude was determined as $\mathrm{Mw}=7.2$. Thousands of aftershocks with intermediate magnitude followed the main shock, such as the aftershock that occurred on November 23, 1995 with a local magnitude of $M_{L}=5.4$. The best estimate of the focus location was determined in the area between Dahab and Nuweiba cities. This great earthquake was felt in Lebanon, Syria and Israel in the North and Egypt, Saudi Arabia and Sudan in the South. The touristic areas surrounding the Gulf of Aqaba were mostly affected. Different accelerograms for this great earthquake were collected and soil responses spectra for Sinai Peninsula and some Jordanian soils were calculated. The design response spectrum shows an average spectral acceleration of about $250 \mathrm{~cm} / \mathrm{sec}^{2}$ for frequency range between 1 - $10 \mathrm{HZ}$. Soil Amplifications were then calculated using Microtremors site response technique and maximum spectral accelerations filtered by the soil were in range between $120-450 \mathrm{~cm} / \mathrm{sec}^{2}$ for the study area. The analysis presented here is intended to be used in the future to allow reducing the seismic risk, help in proper structural design and detailing of buildings and structures to account for beam-column connections and shear reinforcement.
\end{abstract}

\section{Keywords}

Sinai Peninsula, Response Spectrum, Soil Response, Spectral Acceleration, 
Seismic Hazard, Gulf of Aqaba, PGA

\section{Introduction}

It is well known that after the earthquake occurs, the areas that experienced the maximum peak ground acceleration (PGA) are not necessarily showing the maximum damage. This is simply because acceleration is modified and amplified by soil and then again by structure. So one of the most important parts in making seismic hazard analysis is to make assessment for the soil. The soil response may increase or decrease the effect of the earthquake based on its composition. The present work is very important for two reasons: one is that it uses the spectral acceleration which is very rare in this area to accurately show acceleration values carried on which frequencies, second to make soil frequency analysis to know the amount of energy that will enter this soil and consequently the structures. Such work is very important for engineers to know the specific effect that their design will suffer especially when they know its resonance frequency. So the fundamental natural frequency of the soils and structures is very important in seismic hazard assessment. For this reason, the concept of the response spectra was introduced. This important engineering quantity is determined from the original earthquake ground motion by using narrow band-pass filters that acts like simple oscillators or structures [1]. The response spectrum is very useful in the design of buildings, because we can deal with structures like simple damped harmonic oscillators and show the maximum corresponding acceleration response that the structures will suffer during earthquakes, based on its natural frequency, and consequently determine the magnitude of force that will affect these structures during earthquake excitation [2] [3]. Earth tends to act like a low pass-filter on propagating seismic waves. That is, the high-frequency spectral components are attenuated more rapidly than low-frequency components [4]. Unfortunately, few response spectrum records are available in Egypt, most probably due to the lack of ground motion recordings. Tripartite diagram is used to define the amount of displacement, velocity or acceleration that constructions will suffer during all earthquake excitation in a specific site. It is very important that this spectrum is accurately determined taking into consideration all various conditions including path effects, local site geology, topography and all variables that could change the spectral response until it reaches the structure under consideration. Although the response spectrum is a soil dependent engineering quantity, many scientists have used generalized response spectra to account for many soil types. There are two types of soil response spectra: soil dependent response spectrum and soil independent response spectrum. The design response spectrum of the Aqaba area was calculated using the Main shock recorded at November 22, 1995 and some other aftershocks recorded at the surrounding areas at which stations were available such as Dahab and Nuweiba. Soil response was calculated for some Egyptian and Jordanian soils using the Micro- 
tremors site response. A final maximum spectral acceleration map was introduced by filtering the spectral acceleration by soil taking into consideration the amplification values for each soil.

\section{Determination of Response Spectrum}

Simple systems such as simple pendulum can be used for simulating the performance of simple structures during earthquake excitation [4]. The response spectra of the structures can be in the form of displacement, velocity, acceleration or all of them in one graph (Tripartite diagram). In all cases each structure is treated as simple damped oscillator which has definite natural frequency of vibration. Different structures are affected by different ground motions based on the original spectral composition of the ground motion and of course the most damaging parameter in earthquake excitation which is the duration of the ground motion.

The main types of displacement, velocity or acceleration responses are:

1) Relative Displacement (RD)

2) Relative Velocity (RV)

3) Pseudo Relative Velocity (PSRV)

4) Absolute Acceleration (AA)

5) Pseudo Absolute Acceleration (PSAA)

Where,

$\mathrm{RD}$ : is the maximum value of relative displacement of the simple system during vibratory Motion,

$\mathrm{RV}$ : is the true relative velocity of oscillator,

PSRV: is the maximum velocity relative to its base, of the center of mass of resonant simple structure.

AA: is the true absolute acceleration of oscillator and

PSAA: is the measure of maximum elastic spring force per unit of mass.

PSAA is actually quite close to AA but PSRV can be quite different from RV.

\subsection{Soil Independent Response Spectrum}

The soil independent procedure is based on the use of standard spectrum shapes. The standard spectrum shapes are considered to be independent regardless of the characteristics of the site because the original seismograms from which the spectra were derived depict ground motions for a wide range of geological and seismological conditions. Housner 1959 [5] first introduced site-independent response spectrum. He used two horizontal components of ground motion for four large earthquakes recorded at four sites to derive a smoothened and normalized velocity and acceleration response spectra (Figure 1).

Another technique used is the relation between damping of response spectrum for a certain range of frequencies and the amplification factors which is shown in Figure 2 [6]. In this method the peaks of ground displacement, velocity and acceleration are normalized and all are then plotted in one graph (Tripartite diagram). Using the amplification factors for certain frequency range and critical 


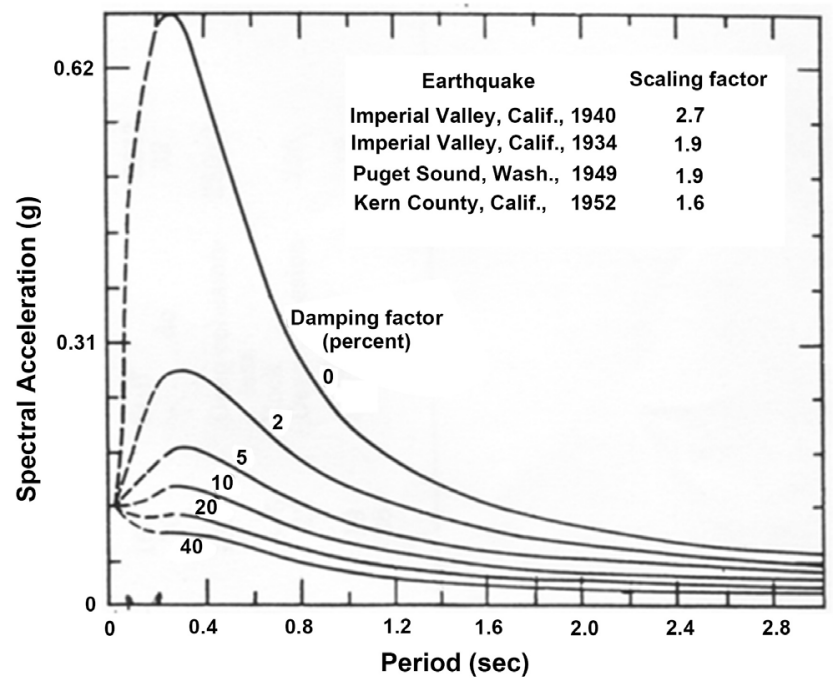

Figure 1. Site-independent acceleration response spectrum [5].

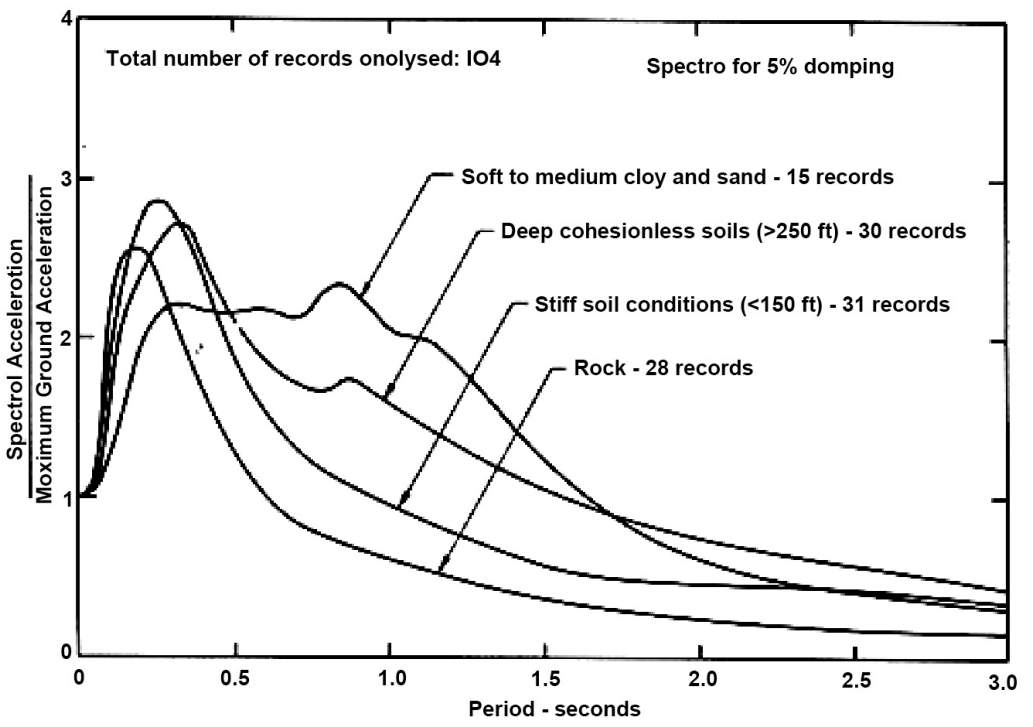

Figure 2. Smoothed site-independent response spectrum for $0.33 \mathrm{~g}$ earthquake, $2 \%$ critical damping [6].

damping, the peak ground motion values are shifted or amplified and smoothened to give the design response spectrum at the specific site. The derived response spectrum discussed by Newmark and Hall [6], 1969 is determined when parameters of ground motion are available (Peak ground displacement, velocity and acceleration).

In 1973, another important "soil-independent response spectra" was introduced by the U.S. Atomic Energy Commission (AEC) in which the same idea of normalizing amplification factors was used by (Newmark and Hall, 1969) [6] (Figure 3). However, the method requires data from a large number of earthquakes. The amplification was also controlled using only four points $\mathrm{A}, \mathrm{B}, \mathrm{C}$ and D distributed over the spectrum for certain frequency range. 


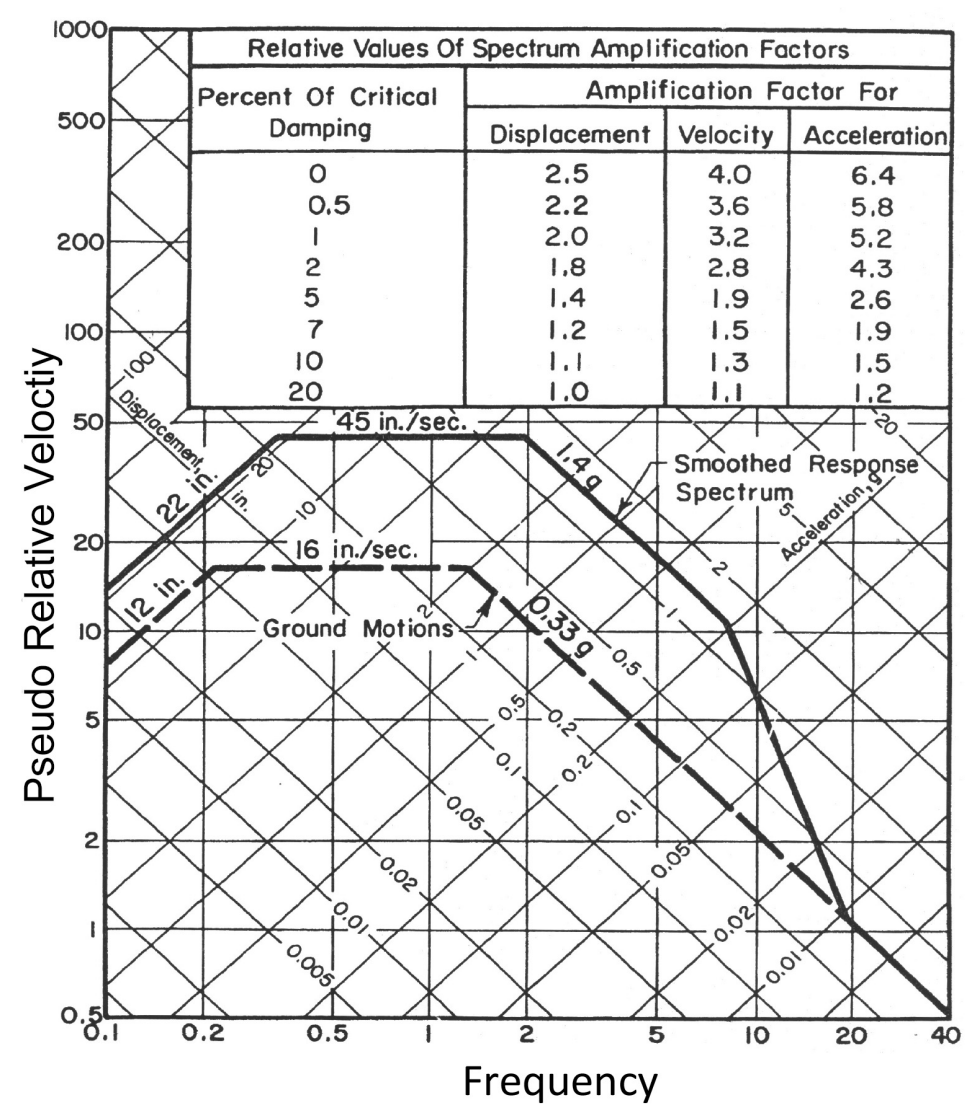

Figure 3. Site independent horizontal response spectra scaled to $1.0 \mathrm{~g}$. A to $\mathrm{D}$; Are the controlling points of amplification at certain frequency ranges [8] (U.S. atomic energy commission, 1973b).

\subsection{Soil Dependent Response Spectrum}

The "soil dependent response spectrum" was introduced before the "soil independent response spectrum". The soil dependent response spectrum uses similar seismograms recorded over soils having the same geological and seismological conditions. However, it is very difficult to find a set of ground motion data having the same or similar source focal mechanism, attenuation path and soil conditions to determine soil dependent response spectrum. Seed et al., 1976 [7], collected a set of 104 accelerograms to determine soil dependent response spectra for four different soil types (Figure 4):

a) Rocky soils (28 accelerograms),

b) Stiff soils (31 accelerograms),

c) Cohesionless soils (30 accelerograms)

d) Soft and Medium clayey soils (15 accelerograms).

[7] Seed et al., 1976 concluded that "soft and medium" soils or "cohesionless soils" have high amplification factors (Spectral acceleration/maximum ground acceleration) for low frequencies $\leq 3 \mathrm{~Hz}$. While the amplification from rocks or stiff soils is higher at higher frequencies $\geq 6 \mathrm{~Hz}$ (Figure 4).

This was found to be in a good agreement with [9] Smoots et al., 1969, who proved that thick soft soils have long amplification period or low amplification 


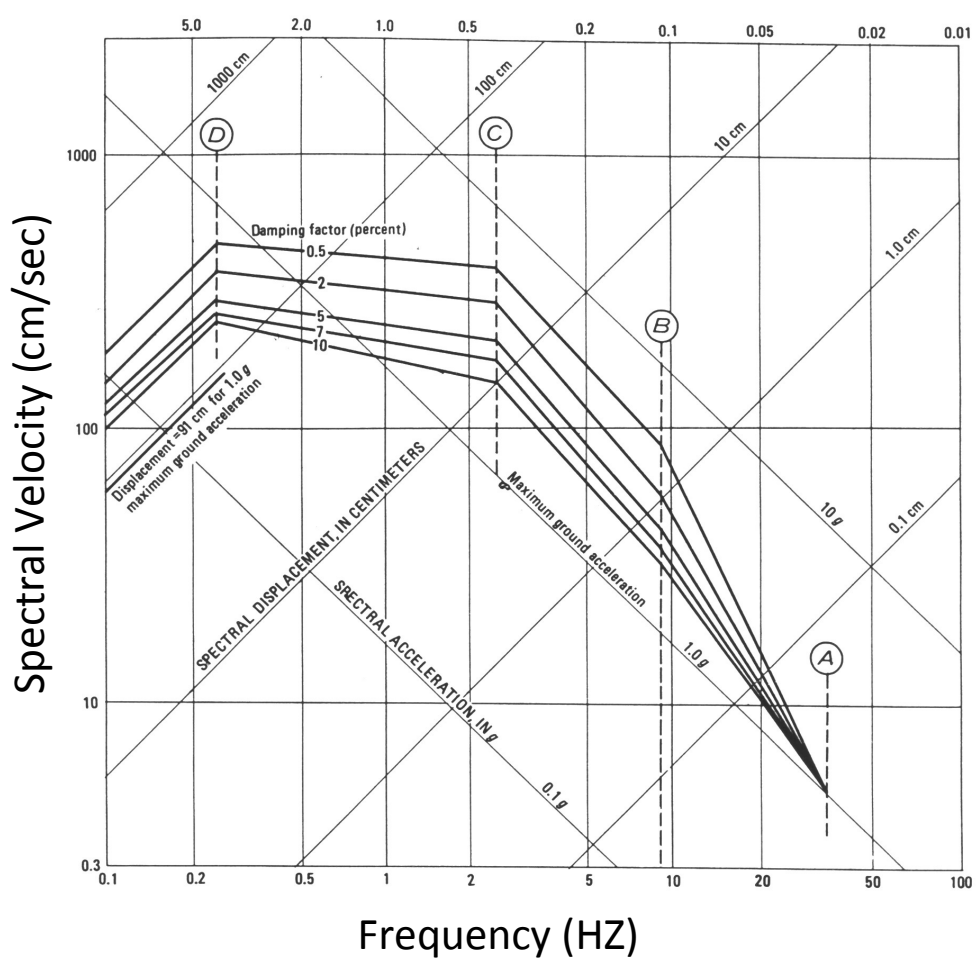

Figure 4. Average acceleration response spectra for different site classifications [7].

frequency when compared with rocky or stiff soils (Figure 5). In brief, soft soils tend to amplify the ground motion response at low frequencies $(\leq 3 \mathrm{~Hz})$, while rocky or stiff soils tend to amplify the ground motion response at high frequencies $(\geq 6 \mathrm{~Hz})$.

\section{Damage Reports of the Great Aqaba Earthquake, 1995}

Damages of the Aqaba earthquake were distributed in a large area and many cities ranging from Jordan in the North to Sudan in the South. This is most probably due to the large magnitude of the earthquake [10]. The following is a brief description of the damages in different countries:

\subsection{Egypt}

Most of the severe damages were occurred in Egypt for old and deteriorated buildings which were not properly designed to resist earthquake loads. Severe damages were occurred in many cities from Nuweiba (about $35 \mathrm{~km}$ from focus) until Cairo (About $370 \mathrm{~km}$ from the epicenter). The majority of the damage was occurred at the city of Nuweiba on the Gulf of Aqaba (Figure 6 and Figure 7). According to Egyptian officials, five people were killed and 38 were injured. About fifty houses and thirty three schools were affected or damaged. Old houses and poorly constructed schools in Cairo, Suez, Port Said and Ismailia were also affected [10]. In Dahab city, almost all buildings in the city were suffered because of its proximity to the focus. Most of the large damages were occurred at 


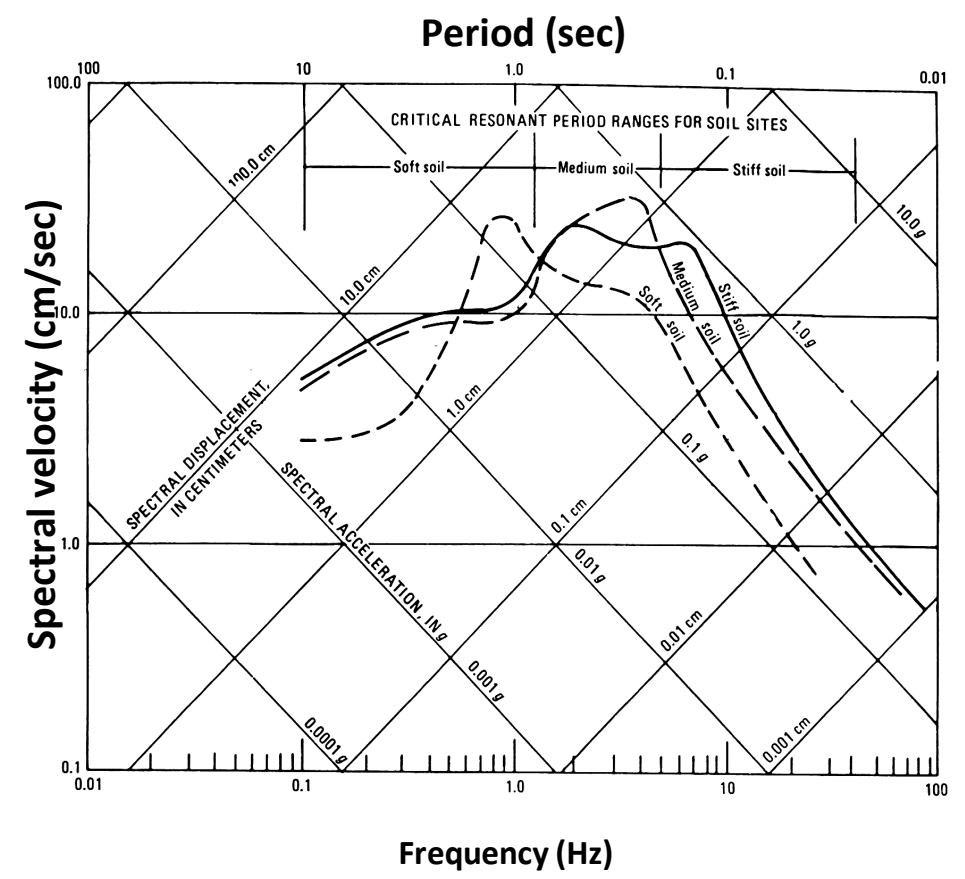

Figure 5. Response spectra for different soil types [9] Smoots et al., 1969.

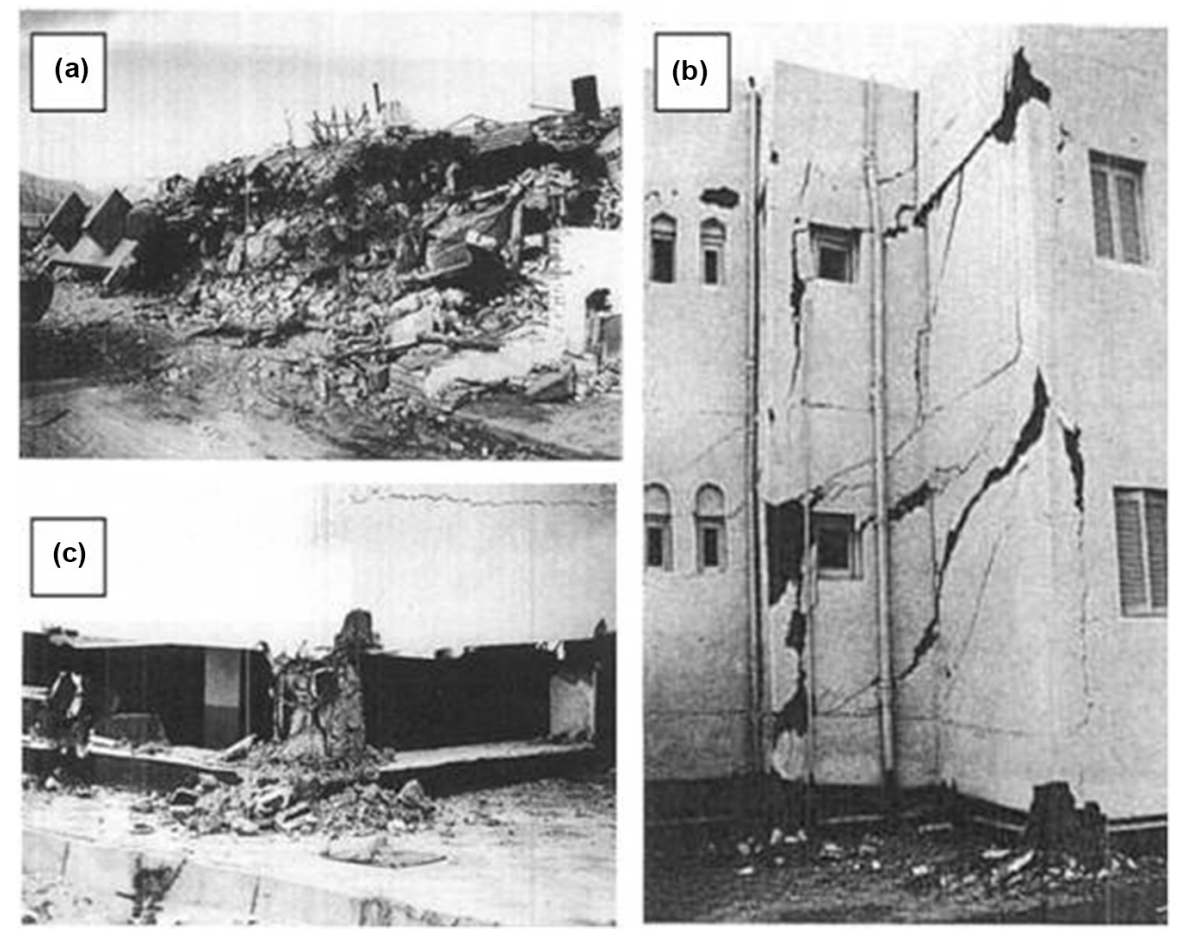

Figure 6. Several Structural damages due to Aqaba 1995 earthquake, (a) The total collapsed three-story Paracoda Hotel in Nuweiba, (b) Failure of a two-story building and (c) Collapse of columns of two story building [10].

Nuweiba city, including failure of the port quay-wall due to liquefaction. The three-story Paracoda hotel was shattered completely and some other hotels were suffered damages (e.g. Dolphin village, Coral, Helnan). Other very important 


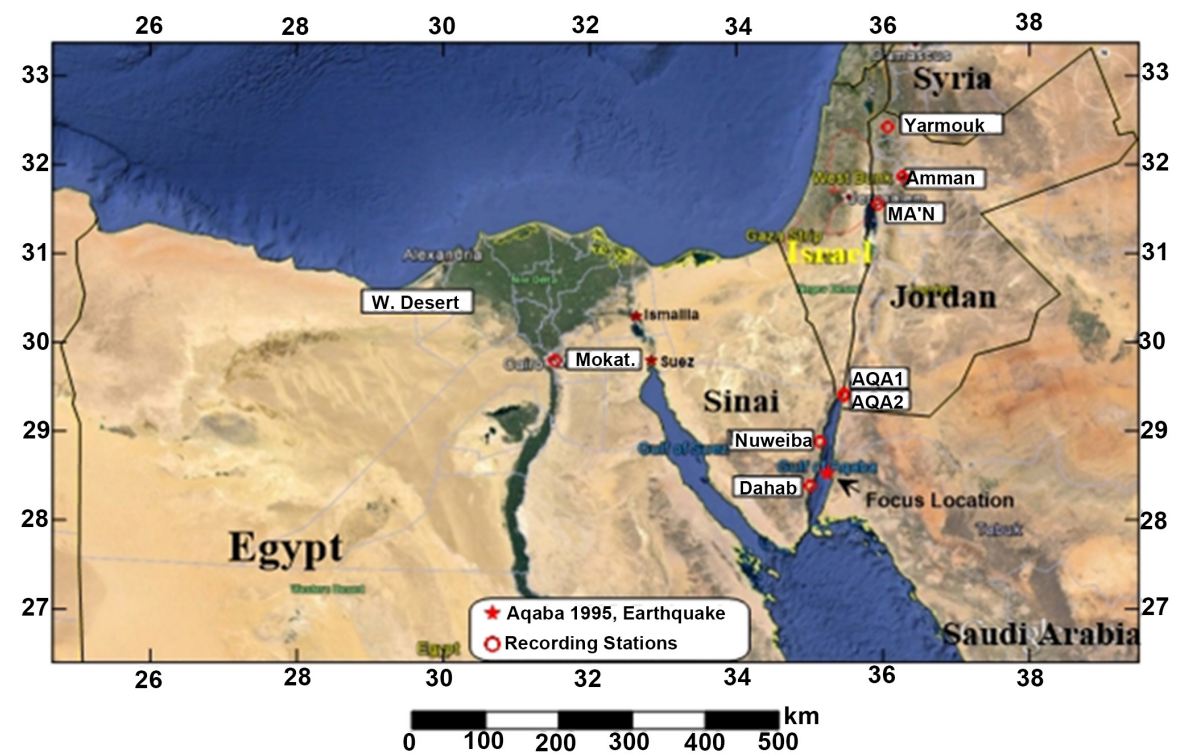

Figure 7. Aqaba 1995 earthquake focus location [12] and locations of recording stations.

structures such as the distillation plant and electrical power plant were subjected to damages causing loss of electricity. The damages were also observed along the roads between Dahab and Nuweiba by stones falling from hills.

\subsection{Jordan}

In the town of Aqaba one poorly constructed building was collapsed [10]. Cracks and nonstructural damage were experienced by almost all buildings. Minor structural damages were observed in the Aqaba Hotel. Some monuments in the historical city of Eilat were damaged.

\subsection{Israel}

One person was died from a heart attack and several others were injured. In the port city of Eilat, damage in the Sport Hotel on the gulf beach was reported [10]. Cracks in fill walls in almost all buildings were observed. Ground fractures and cracking of road surfaces were noted. Liquefaction was observed close to the gulf coast.

\subsection{Saudi Arabia}

One person was killed and two were slightly injured. At El-Durra customs office $(\sim 90 \mathrm{~km})$, a complete collapse of a free standing shed was occurred. Another collapse of a concrete roof of the passenger terminal at the same facility was reported. The concrete beams carrying the water tank at the Haql border guard headquarters were also damaged [10].

\section{Response Spectra of the Great Aqaba Earthquake}

Different response spectra were obtained for this earthquake. The effect of the great Aqaba 1995 earthquake continued for about $490 \mathrm{~km}$ along the Jordanian 
axis. The recording stations of the earthquake are listed in Table 1. At a distance of about $105 \mathrm{~km}$ away from the earthquake epicenter, the recording station AQA1 (Figure 7, Figure 8 and Table 1) which is underlain by alluvium soil, showed a maximum horizontal spectral acceleration of about $150 \mathrm{~cm} / \mathrm{sec} 2$ at about $1 \mathrm{sec}(1 \mathrm{HZ})$ for $5 \%$ damping.

Recording station AQA2 (Figure 7 and Figure 8) is about $100 \mathrm{~km}$ from earthquake epicenter; its underlying soil is sand. The maximum spectral acceleration obtained is about $350 \mathrm{~cm} / \mathrm{sec}^{2}$ occurs at about $0.8 \mathrm{sec}(1.3 \mathrm{HZ})$.

At a further distance where Amman recording station exists, $390 \mathrm{~km}$ from earthquake epicenter, the effect becomes very weak (Figure 7 and Figure 8). The Amman recording station is founded on sandy soil, where the maximum spectral acceleration is about $10 \mathrm{~cm} / \mathrm{sec}^{2}$ at period about $1 \mathrm{sec}(1 \mathrm{~Hz})$.

The effect of the earthquake at $450 \mathrm{~km}$ is showing a weak spectral acceleration of about $20 \mathrm{~cm} / \mathrm{sec}^{2}$ for Yarmouk station at about $2 \mathrm{sec}(0.5 \mathrm{~Hz})$ (Figure 7) which is founded on alluvium soil. The earthquake was strong enough to reach Cairo city. The recording station of EL Mokatam was by coincidence in operation at about $370 \mathrm{~km}$ from the earthquake epicenter [11] (Figure 7). The underlying soil is mainly limestone rock and the maximum spectral acceleration was found to be about $40 \mathrm{~cm} / \mathrm{sec}^{2}$ at a period of $0.3 \mathrm{sec}(\sim 3.5 \mathrm{~Hz})$ which is relatively higher than the spectral acceleration in Jordanian axis direction $\left(\sim 7 \mathrm{~cm} / \mathrm{sec}^{2}\right.$ at Amman, $390 \mathrm{~km}$ away from the epicenter), this could be attributed to the difference in attenuation path which is very high in the Jordanian axis, most probably due to the richness in alluvium content.

On February $21^{\text {st }}, 1996$, an aftershock of magnitude 4.7 for the same earthquake was recorded by the Egyptian Geological Survey at Dahab and Nuweiba ( $\sim 35 \mathrm{~km}$ from epicenter). Both stations are initiated over basement rocks (Figure 7). The Maximum Spectral accelerations recorded at Dahab was about $88 \mathrm{~cm} / \mathrm{sec}^{2}$ which occurred at $0.2 \mathrm{sec}(5 \mathrm{HZ})$ and at Nuweiba was about 78 $\mathrm{cm} / \mathrm{sec}^{2}$ at $0.3 \mathrm{sec}(\sim 3.5 \mathrm{HZ})$ for $5 \%$ damping [12].

Table 1. Main shock and aftershocks strong motion recording stations.

\begin{tabular}{cccccc}
\hline Station & M & Date & Ref. & Soil Type & Max. PGA $\left(\mathrm{cm} / \mathrm{sec}^{2}\right)$ \\
\hline Mokat & 7.1 & $22 / 11 / 95$ & CU & Limestone & 8.5 \\
AQA1 & 7.1 & $22 / 11 / 95$ & JSL & Alluvium & 66.5 \\
AQA2 & 7.1 & $22 / 11 / 95$ & JSL & Sand & 157 \\
MA'N & 7.1 & $22 / 11 / 95$ & JSL & Sand & 19.5 \\
Amman & 7.1 & $22 / 11 / 95$ & JSL & Sand & 2.8 \\
Yarmouk & 7.1 & $22 / 11 / 95$ & JSL & Alluvium & 4.6 \\
Nuweiba & 4.7 & $21 / 2 / 96$ & EGS & Basement & 22.6 \\
Dahab & 4.7 & $21 / 2 / 96$ & EGS & Basement & 56.2 \\
Nuweiba & 3.9 & $26 / 2 / 96$ & EGS & Basement & 35.2 \\
Dahab & 3.9 & $26 / 2 / 96$ & EGS & Basement & 29.3 \\
\hline
\end{tabular}

CU: Cairo University; JSL: Jordan Seismological Lab; EGS: Egyptian Geological Survey. 

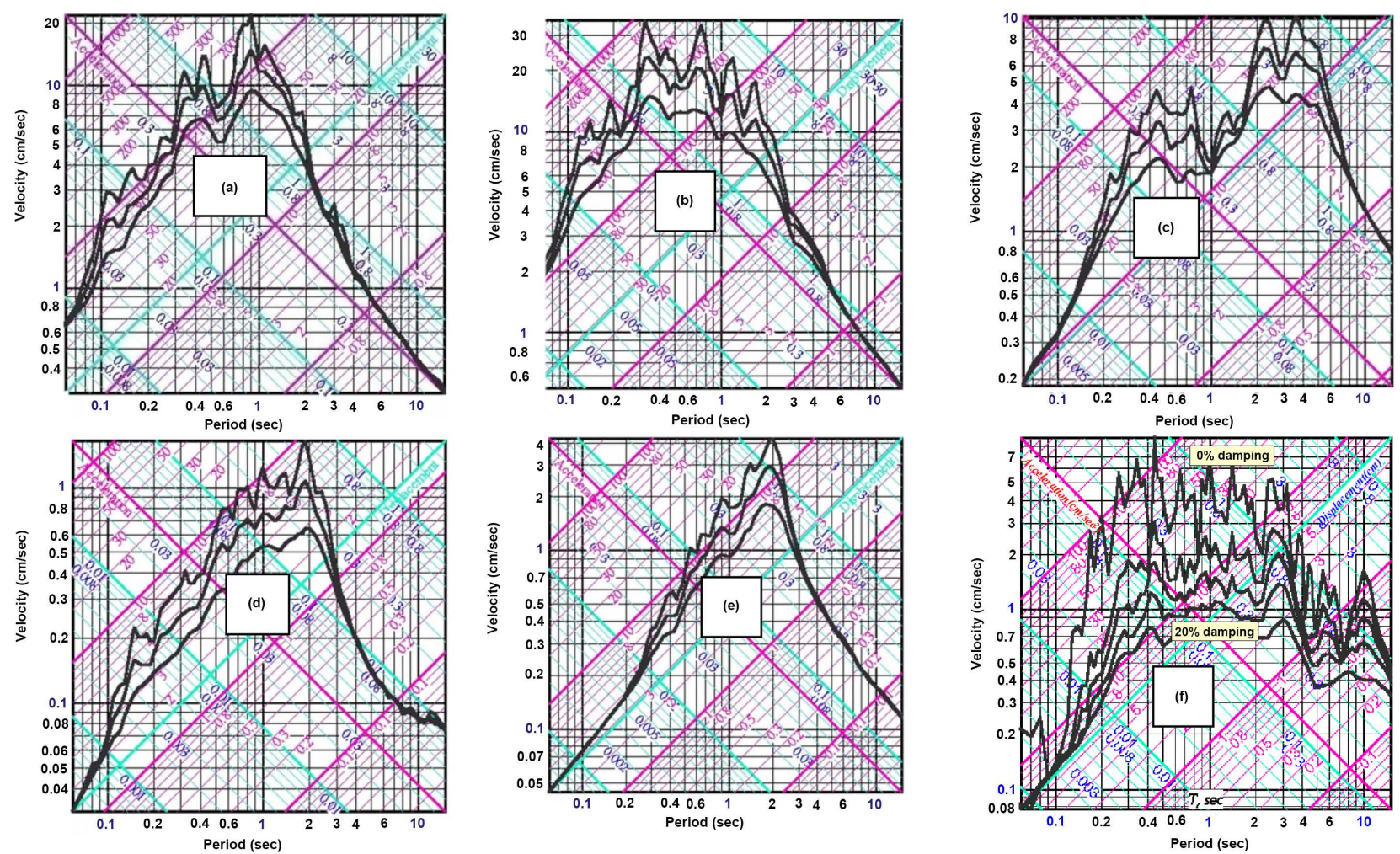

Figure 8. Response spectra for Aqaba, 22/11/1995 earthquake over recording stations A: AQA1, B: AQA2, C: MA’N, D: Amman, E: Yarmouk, F: Mokattam stations (A through E are 5\% damping while F is between $0 \%$ to $20 \%$ ), determined for horizontal components (units are Acc. $=\mathrm{cm} / \mathrm{sec}^{2}$; Vel. $=\mathrm{cm} / \mathrm{sec}$ and Disp. $=\mathrm{cm}$, please refer to Figure 7 for locations of recording stations).

Again on 26/2/1996, an aftershock of magnitude 3.9 for the great Aqaba earthquake was recorded by the same stations [12]. The maximum spectral acceleration obtained by Nuweiba was about $68 \mathrm{~cm} / \mathrm{sec}^{2}$ obtained at $0.35 \mathrm{sec}(2.8$ $\mathrm{HZ}$ ) while for Dahab was nearly the same obtained at $0.2 \mathrm{sec}(5 \mathrm{HZ})$ [12].

\section{Average Design Response Spectrum for Gulf of Aqaba Region}

Average design response spectrum for Aqaba region was determined using the main shock recorded on November 22, 1995 over the Jordanian soil at stations AQA1 (Alluvium) and AQA2 (Sand). We used also the recorded aftershocks for the same earthquake occurred on November 21, $1996(\mathrm{M}=4.7)$ and November 26, $1996(\mathrm{M}=3.9)$ at the city of Dahab and Nuweiba over the basement rocks. These are considered as moderate earthquakes affected the Gulf area. The spectral acceleration obtained was normalized to average damping value of 5\% (Figure 9). The average design response spectrum shows an average acceleration value of about $220 \mathrm{~cm} / \mathrm{sec} 2$ for frequency range $1.5-10 \mathrm{HZ}$.

\section{Soil Reponses for Sinai Peninsula and some Jordanian Soils}

The Microtremors site response method [11] was used to determine the soil natural frequency of vibration and amplification factor for Aqaba-Amman path 


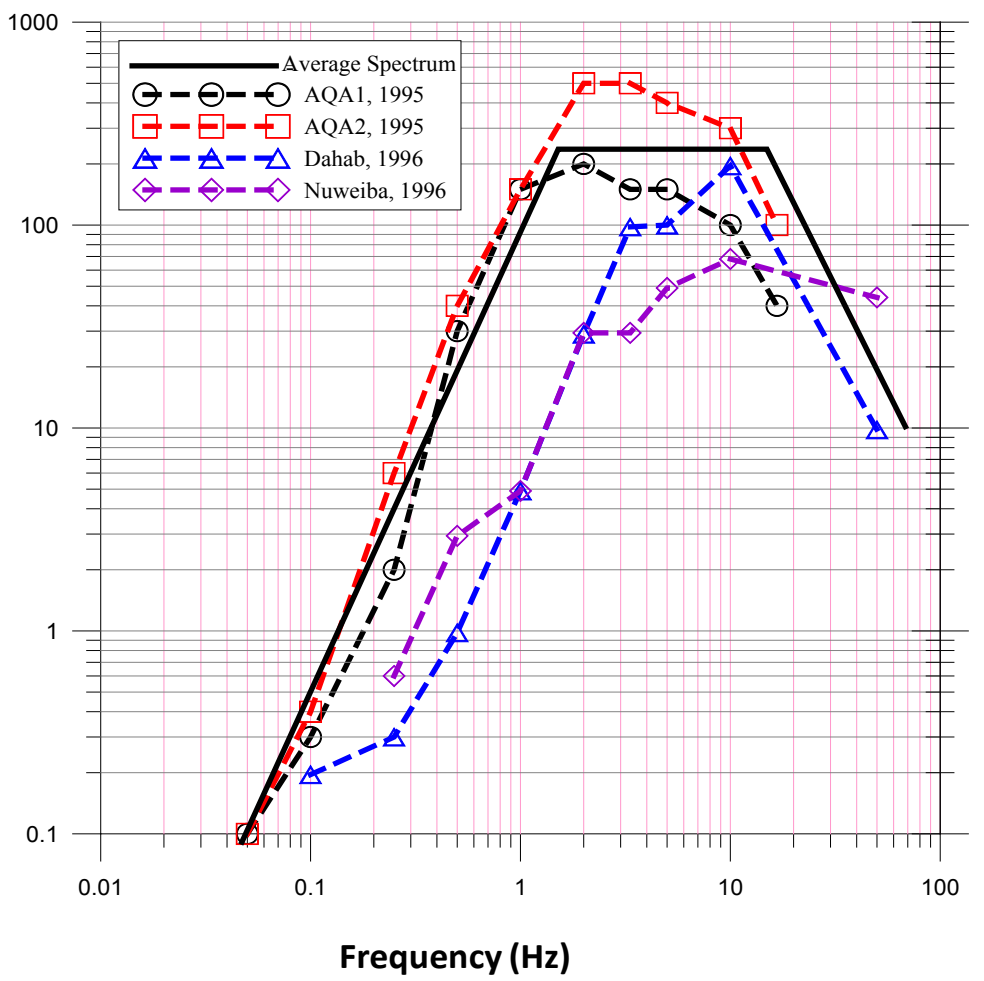

Figure 9. Average design response spectrum for Gulf of Aqaba region.

for the Jordanian soils (Figure 10, Figure 11 \& Table 1). A Kinemetrics Altus-K2 acceleration station was used to determine the site response for 19 soil stations shown in Figure 10. Microtremors soil response method is described in details by Mohamed Gamal, 2008 [11]. The following steps were applied to determining Microtremors soil response for S1-S19 for Aqaba-Amman path:

1) Recording 15-min of Microtremors at a fixed reference station (representing soil base) and another mobile station moving among variable Jordanian sites simultaneously (both stations work together and synchronized in time),

2) Zero correction to the total 15-min. Microtremors noise at time domain was applied,

3) We then subdivided each 15-min. Microtremors signal into fifteen 1-min sub windows, each of these series was tapered with a 3-sec hanning taper and converted to the frequency domain using a Fast Fourier transform,

4) We then smoothed the amplitude spectrum by convolution with $0.2 \mathrm{~Hz}$ boxcar window,

5) Soil response of a given site location is derived by dividing the average spectrum of the mobile station for all processed 15 sub windows at each site; over the response of the reference station recorded over the nearest bedrock (best rocky site nearby the recording station).

6) After that, we smoothed the final response curves by running average filter for better viewing. A complete description to the methodology can be found in [11] Mohamed Gamal, 2008. 


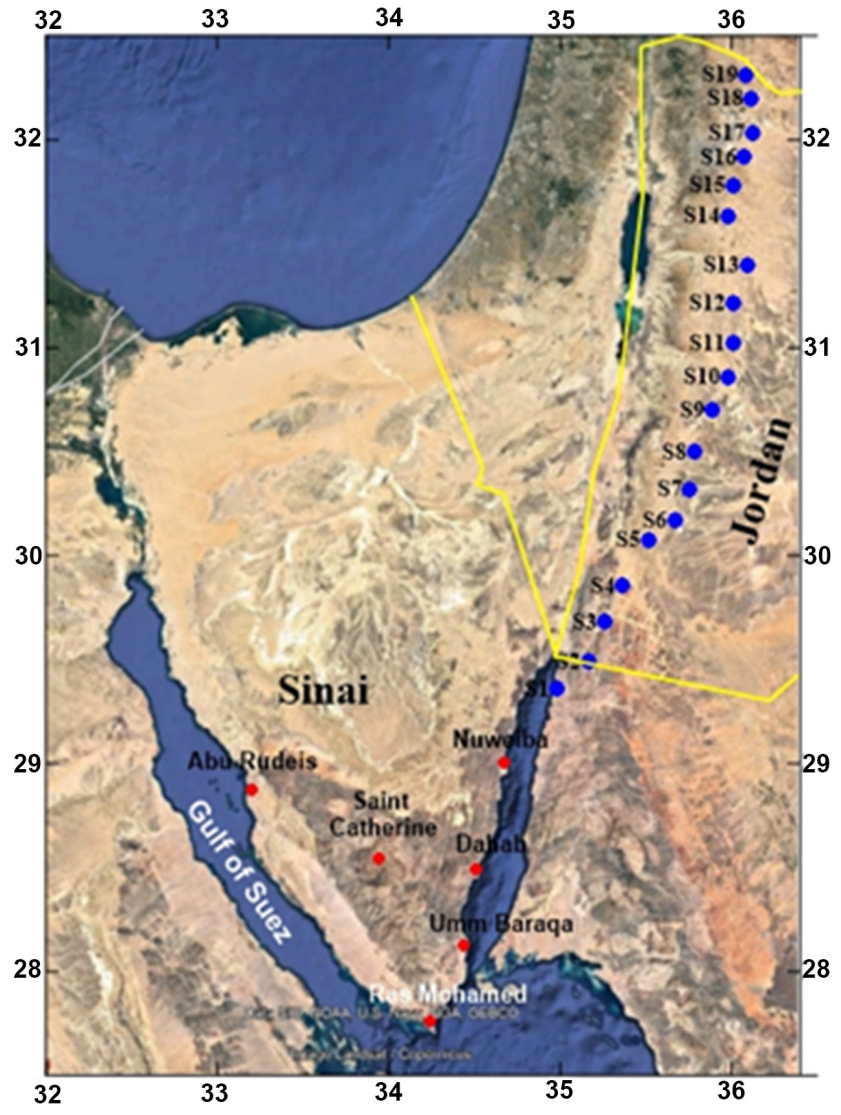

Figure 10. Locations of the stations used to derive soil response for this study.

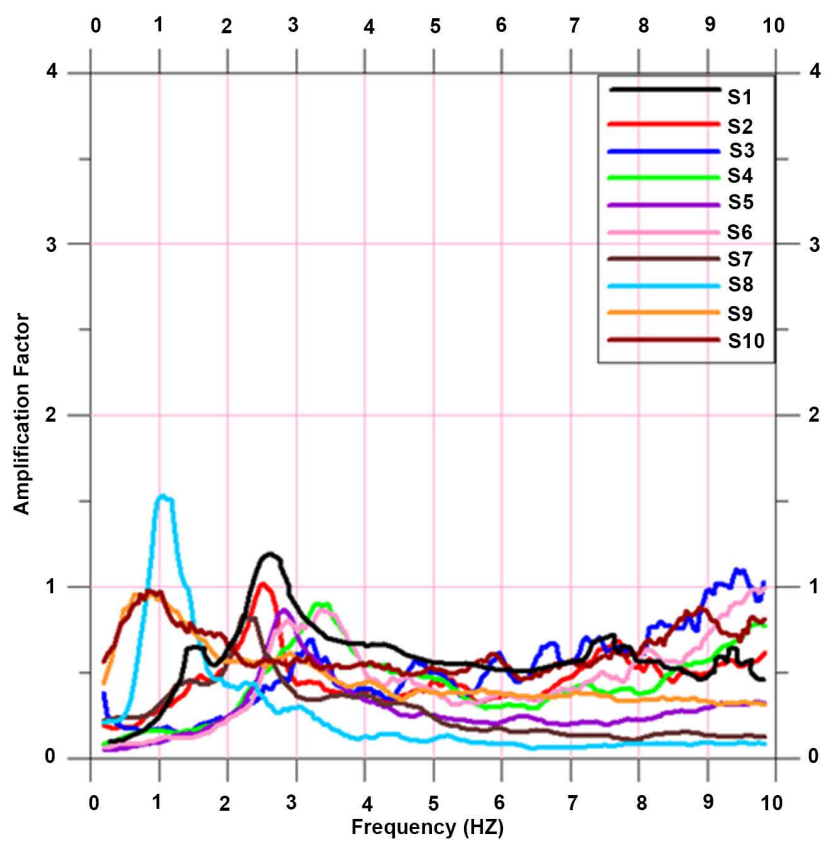

(a)

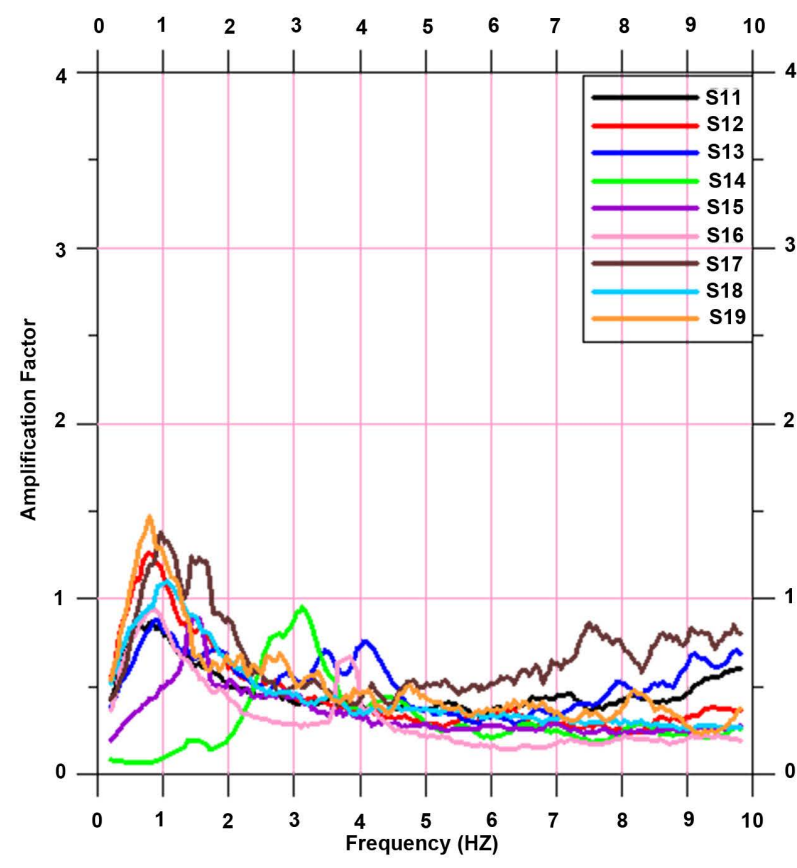

(b)

Figure 11. Microtremors soil response for Jordanian soils [a]: S1 to S10 and [b]: S11 to S19 (Please refer to Figure 10 for site locations). 
For the Egyptian soils like Umm Baraqa and Ras Mohamed, the response was determined using [13] Kennett and Kerry, 1979 Method while Microtremors site response was used for other sites like Abu Rudeis and Saint Katherine (Figure $11 \&$ Table 2).

\section{Frequency Map and Maximum Spectral Acceleration Map}

Soil frequency map was introduced using the fundamental natural frequency of vibration for the Jordanian and Egyptian soils surrounding the Gulf of Aqaba. Different soil composition were found in the gulf area such as the clay deposits found at Umm Baraqa or basement rocks found at Saint Catherine region (Figure 12). The frequencies are variable between $1-10 \mathrm{~Hz}$. The maximum frequency is obtained in central Sinai at which the Basement mountains are found composed mainly of granite, while the relatively lower frequencies $(\sim 4 \mathrm{HZ})$ are found surrounding the Gulf Aqaba area at which the fan deposits of mainly clay exist (e.g. Dahab and Umm Baraqa).

Maximum Spectral acceleration Map for Sinai and surrounding Jordanian soils was then determined using the generated design response spectrum (Figure 9) and soil frequency map (Figure 13) and soil amplification values determined for each site in this study (Table 1). The Maximum spectral acceleration map is showing Sinai splits between two parts; the western part is showing maximum spectral acceleration between $120-250 \mathrm{~cm} / \mathrm{sec}^{2}$ while the Eastern part is showing maximum spectral acceleration between $280-440 \mathrm{~cm} / \mathrm{sec}^{2}$. The Jordanian soil in the path Aqaba-Amman is showing maximum spectral acceleration between 150 - $250 \mathrm{~cm} / \mathrm{sec}^{2}$. The Gulf area is surrounded by maximum spectral acceleration between $300-440 \mathrm{~cm} / \mathrm{sec}^{2}$. (Figure 14)

\section{Conclusions}

The fundamental natural frequency of vibration for the Sinai Peninsula and some Jordanian soils was determined using microtremors site response [11] and theoretical site response of [13] Kennette and Kerry, 1979. Nineteen soil sites were used for the Jordan soils, while six sites were used for Sinai region. Natural frequency map of the Jordanian soils and Sinai Peninsula showed frequency range between $1-10 \mathrm{~Hz}$. The maximum frequency is obtained in central part of Sinai at which the Basement rocks are found, while the relatively lower frequencies ( 4 HZ) are found surrounding the Gulf Aqaba area, composed mainly of clays (e.g. Dahab, Umm Baraqa and Nuweiba cities).

Design response spectrum for the Gulf of Aqaba region was calculated using four response spectra recorded at four stations. Two stations recorded the main shock AQA1 $(\mathrm{M}=7.1,1995)$; AQA2 $(\mathrm{M}=7.1,1995)$ and another two stations recorded moderate values aftershocks, Dahab $(M=4.7,1996)$ and Nuweiba ( $M$ $=4.7,1996)$. The average design response spectrum showed an average value of $220 \mathrm{~cm} / \mathrm{sec}^{2}$ for frequency range $1.5-10 \mathrm{HZ}$.

Maximum Spectral acceleration Map for Sinai and surrounding Jordanian soils was then determined using the generated design response spectrum, soil 
Table 2. Natural frequency of vibration obtained for the Aqaba-Amman path for the Egyptian and Jordanian soils.

\begin{tabular}{|c|c|c|c|}
\hline Site & $\begin{array}{l}\text { Distance from Gulf of Aqaba } \\
\qquad(\mathrm{Km})\end{array}$ & $\begin{array}{c}\text { Fundamental Resonance } \\
\text { Frequency }(\mathrm{HZ})\end{array}$ & $\begin{array}{l}\text { Amplification } \\
\text { Factor }\end{array}$ \\
\hline $\mathrm{S} 1$ & 0 & 2.5 & 1.1 \\
\hline S2 & 25 & 2.3 & 1 \\
\hline S3 & 50 & 3.1 & 0.65 \\
\hline $\mathrm{S} 4$ & 75 & 3.2 & 0.85 \\
\hline S5 & 105 & 2.9 & 0.85 \\
\hline S6 & 126 & 3.4 & 0.85 \\
\hline S7 & 145 & 2.2 & 0.8 \\
\hline S8 & 165 & 1 & 1.35 \\
\hline S9 & 192 & 0.8 & 0.9 \\
\hline S10 & 212 & 0.9 & 0.9 \\
\hline S11 & 232 & 0.9 & 0.85 \\
\hline S12 & 252 & 0.9 & 1.2 \\
\hline S13 & 285 & 0.8 & 0.85 \\
\hline S14 & 305 & 3.1 & 0.9 \\
\hline S15 & 325 & 1.5 & 0.75 \\
\hline S16 & 343 & 0.9 & 0.9 \\
\hline S17 & 360 & 1 & 1.35 \\
\hline S18 & 380 & 1 & 1.1 \\
\hline S19 & 394 & 0.9 & 1.4 \\
\hline
\end{tabular}

frequency map and soil amplification values determined for each site in this study. The Maximum spectral acceleration map splits Sinai into two parts: the western part which is showing maximum spectral acceleration between 120 - 250 $\mathrm{cm} / \mathrm{sec}^{2}$ and the Eastern part which is showing maximum spectral acceleration between $280-440 \mathrm{~cm} / \mathrm{sec}^{2}$. The Jordanian soil in the path Aqaba-Amman is showing maximum spectral acceleration between $150-250 \mathrm{~cm} / \mathrm{sec}^{2}$. The Gulf area is surrounded by maximum spectral acceleration between $300-440$ $\mathrm{cm} / \mathrm{sec}^{2}$.

Although the distance between the epicenter of the great earthquake of Aqaba 1995 , and both capitals of Jordan and Egypt are nearly the same $(\sim 380 \mathrm{~km})$, the spectral acceleration recorded in the direction of the capital of Jordan axis is showing a higher rate of attenuation $\left(5-10 \mathrm{~cm} / \mathrm{sec}^{2}\right.$, Amman) rather than in the direction of the capital of Egypt $\left(\sim 40 \mathrm{~cm} / \mathrm{sec}^{2}\right.$, Cairo). This is mainly due to the attenuation path and the nature of the overlying soil which is alluvium and sandy in the direction of Amman, while basement rocks are abundant in the direction of Cairo city at the Sinai Peninsula.

Most buildings found in the region of the Gulf of Aqaba are of few floors $<7$ floors (in resorts and touristic areas or small villages). These buildings have 


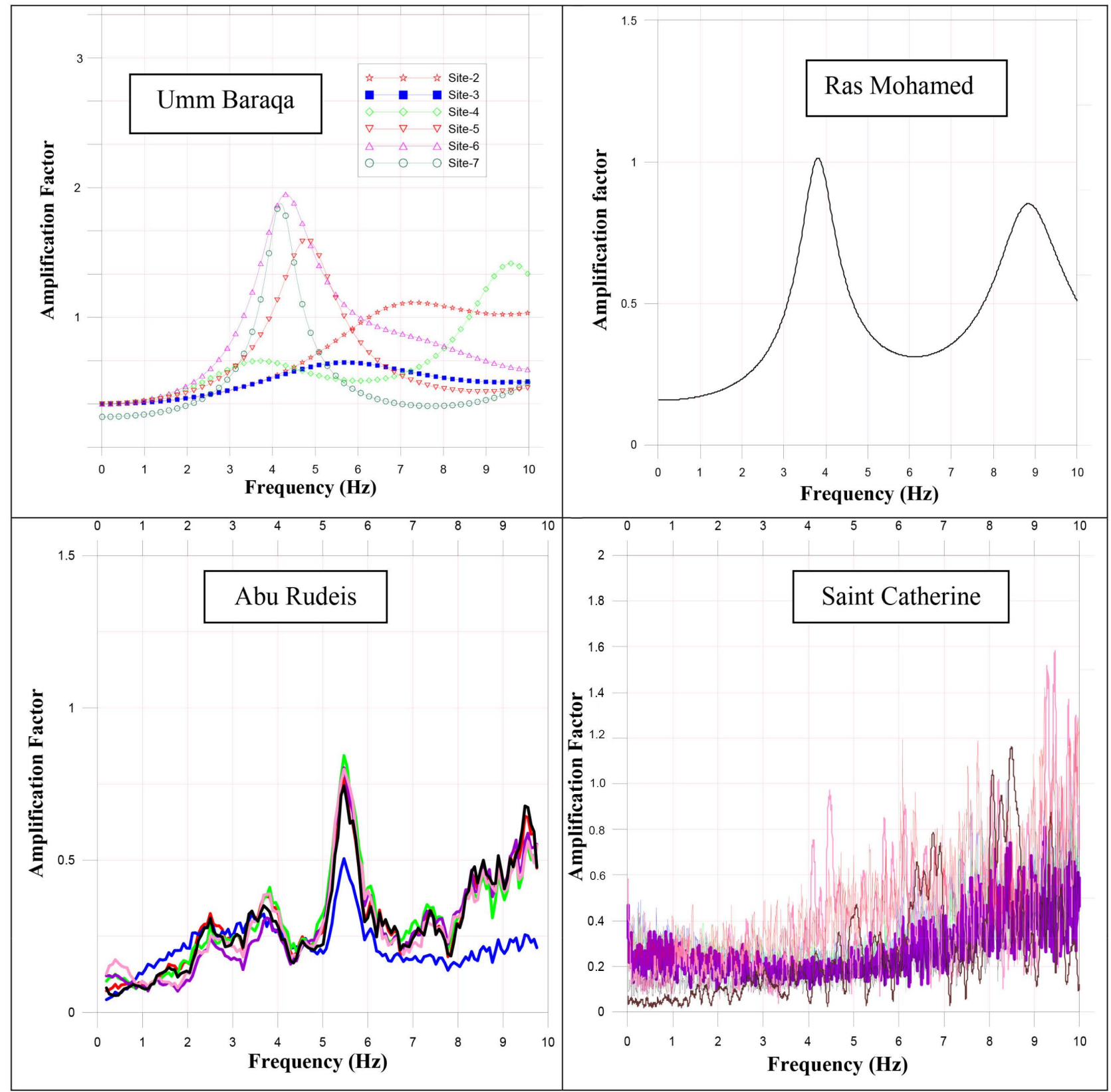

Figure 12. Soil response for the Egyptian soils (Please refer to Figure 9 for site locations). Umm Baraqa and Ras Mohamed responses are determined using [13] Kennett and Kerry, 1979. Saint Catherine and Abu Rudeis sites are derived using Microtremors site response described above.

natural frequencies of vibration between $5-10 \mathrm{~Hz}(0.1-0.2 \mathrm{Sec})$. It may be concluded that they will be suffering from high spectral acceleration of about 220 $\mathrm{cm} / \mathrm{sec}^{2}$ over the bedrock (Sites like Saint Catherine and rock sites where no amplification exist).

Based on the maximum spectral acceleration map and the damage reports in the cities surrounding the Gulf of Aqaba, an important conclusion is that, the spectral acceleration will exceed the values of the maximum recorded accelerations to reach the level of $440 \mathrm{~cm} / \mathrm{sec}^{2}$, especially over the soils of thick and soft 


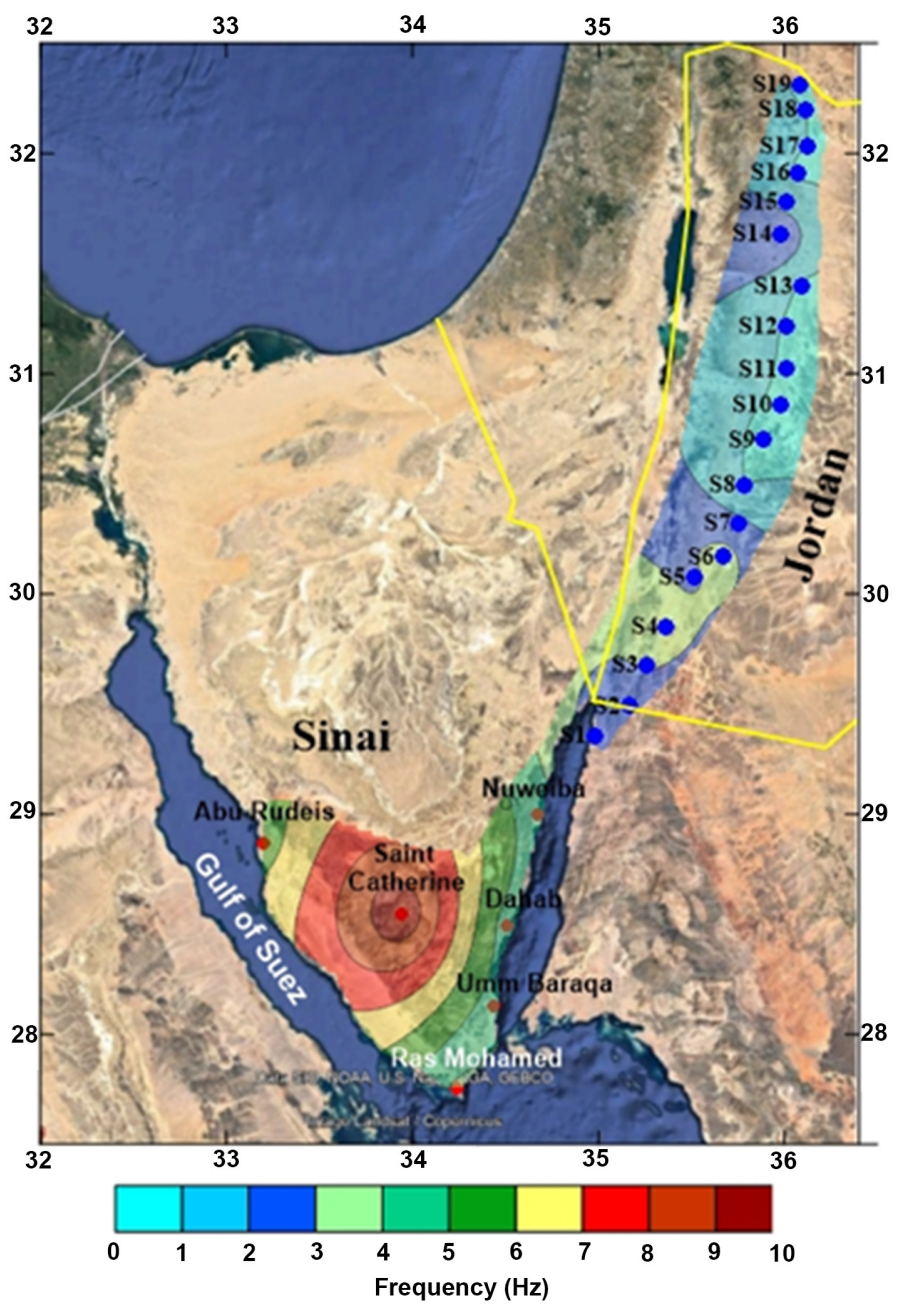

Figure 13. Soil frequency map for the Egyptian and Jordanian soils showing the stations used to determine the natural frequency of vibration.

deposits. This is in good agreement with the damage reports for the area surrounding the gulf such as Dahab and Nuweiba which showed that almost all buildings had suffered from damages without shattering. This occurred in the main shock recorded on November $22^{\text {nd }}, 1995$.

It is recommended to increase the level of the maximum expected acceleration in the Gulf area to $\geq 440 \mathrm{~cm} / \mathrm{sec}^{2}$. This should be taken into consideration especially when initiating new structures, resorts and hotels. Without taking into consideration these high levels of spectral acceleration, the proper structural design and detailing of shear reinforcement will be affected. This may cause construction instabilities and ultimately complete collapse as was observed in 1995 Aqaba earthquake for buildings in cities of Dahab and Nuweiba in Egypt.

It is important also to realize that the natural frequencies of vibration in this study are not sufficient to account for all soil changes. So other elaborated studies should take into consideration this note and make more extensive work to account for all soil variations. 


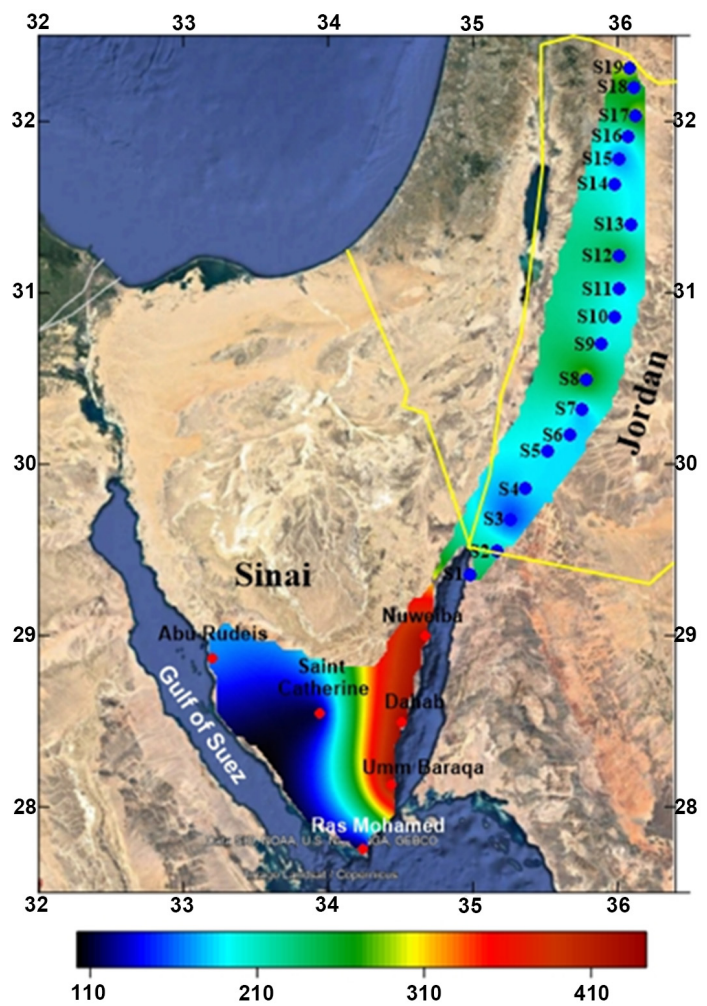

Figure 14. Maximum Spectral acceleration Map for Sinai and surrounding Jordanian soils determined using the generated design response spectrum (Figure 8) and soil frequency map (Figure 12) and soil amplification values determined for each site in this study (Table 1).

The area of the Gulf of Aqaba need more spectral acceleration recordings in order to account for different soil dependent and soil independent response spectra and help making mare accurate design response spectrum. This can be done using at least 100 acceleration times history. This could be achieved when more acceleration stations is planted in this area especially in the Egyptian part.

\section{Acknowledgements}

We would like to thank the Jordan Seismological Observatory for giving raw data for Aqaba 1995 Earthquake, Dr. Amarat and all Jordan Seismological Observatory team. Also thanks for Drilling Geophysics Co. which provided raw data in the Jordanian part "Jordan-Gas-Pipeline project".

\section{Conflicts of Interest}

The authors declare no conflicts of interest regarding the publication of this paper.

\section{References}

[1] Chopra, A.K. (1981) Dynamics of Structures, a Primer Earthquake Engineering Research Institute. 
[2] Benioff, H. (1934) The Physical Evaluation of Seismic Destructiveness. Bulletin of the Seismological Society of America, 24, 398-403.

[3] Boit, M.A. (1943) Analytical and Experimental Methods in Engineering Seismology. Transactions of the American Society of Civil Engineers, 180, 365-375.

[4] Blume, J.A., Newmark, N.A. and Corning, L.H. (1961) Design of Multi-Story Reinforced Concrete Buildings for Earthquake Motion. Chicago, Portland Cement Association, $318 \mathrm{p}$.

[5] Housner, G. (1959) Behavior of Structures during Earthquakes. Journal of the Engineering Mechanics Division, American Society of Civil Engineers, 85, 109-129.

[6] Newmark, N.M. and Hall, W.J. (1969) Seismic Design Criteria for Nuclear Reactor Facilities. 4th World Conference on Earthquake Engineering, 2, 37-50.

[7] Seed, H.B., Ugas, C. and Lysmer, J. (1976) Site Dependent Spectra for Earthquake Resistant Design. Bulletin of the Seismological Society of America, 66, 221-244.

[8] U.S. Atomic Energy Commission (1973) Design Response Spectra for Seismic Design of Nuclear Power Plants. Regulatory Guide 1.60, p. 8.

[9] Smoots, V.A., Gates, W.E., Leeds, D.J. and Mendenhall, J.D. (1969) The Effect of Foundation Soils on Seismic Motion. Soil-Structure Interaction Subcommittee, Structural Engineers Association of Southern California, Seismological Committee, Annual Report, 43-66.

[10] EERI Special Earthquake Report (1996) Earthquake Engineering Research Institute. http://www.eri.org/1995/11/\#eerri

[11] Gamal, M.A. (2008) Using Microtremors for Microseismic Zonation in Cairo's Crowded Urban Areas. Journal of Seismology, 13, 13-30.

https://doi.org/10.1007/s10950-008-9113-3

[12] Basta, N.Z., Salem, E.M., El Shahat, A.M., Habib, A.F., Ahmed, A.E. and El Hakim, B.A. (1996) Seismicity of the Gulf of Aqaba before and after Aqaba 95 Quake. Proceeding of Geological Survey, Egypt, 59-88.

[13] Kennett, B.L.N. and Kerry, N.J. (1979) Seismic Wave in a Stratified Half Space. Geophysical Journal International, 57, 557-583.

https://doi.org/10.1111/j.1365-246X.1979.tb06779.x 